International Review of Social History 43 (1998), pp. 79-109

(C) 1998 Internationaal Instituut voor Sociale Geschiedenis

\title{
Machines and the Order of the Harbour: The Debate About the Introduction of Grain Unloaders in Rotterdam, 1905-1907
}

\author{
DICK VAN LENTE*
}

Summary: In 1905, dockworkers in Rotterdam harbour organized a great strike against the introduction of machines for the transhipment of grain. The initial success of this strike was a profound shock to the leaders of political parties and national labour organizations, who, in spite of many differences of opinion, shared a positive attitude towards mechanization and regarded strikes against machinery as reactionary. The conflict in Rotterdam provoked a national debate about the implications of mechanization, which clearly exposed the strains and contradictions in this "dominant ideology of technology". The article shows how several local labour leaders questioned the legitimacy of this ideology and why they failed in the end to persuade their superiors.

\section{INTRODUCTION}

An advocate from Dordt,

A brewer, a notary,

A foreign potentate,

A stock broker,

They felt a great deal

For the Rotterdam harbour,

Which in their recklessness

They almost dealt a blow of death.

Thus ran the second verse of a protest song called "The Bread Robber", which was passed around among the dockworkers in Rotterdam in $1905 .{ }^{1}$ It was about a recently introduced machine for pumping grain out of ships into lighters. The song said that it would make hundreds of workers lose

* I would like to thank the following for their advice, encouragement and criticism: Johan Schot, Paul van der Laar, Joop Visser, Arjo Klamer, Rina Lis, Hugo van Driel, Bert Altena, Mikael Hard, Andy Jamieson and the editors and referees of this journal.

I. Gemeente-archief Rotterdam, Politie-archief, no. 3354, map 1905, N 7060. It was probably this song that was sung at meetings of the strikers. See De Maasbode, I4 November I905 and Patrimonium, 9 May 1907. 
their jobs. It called the machine the image of the employers who had introduced it: hard and cold, it would suck the lifeblood out of the workers even as it sucked the grain out of the ship; and, it noted sardonically, it is usually employed in the most civilized countries. This machine was called graanelevator (grain elevator) in Dutch. Since the English word usually designates a building for storing grain, I will use the term "grain unloader". The introduction of two of these unloaders in 1905 provoked a strike that paralysed the grain trade in Rotterdam harbour. As a consequence, the Grain Unloader Company was forced to stop using the machines, but two years later the company put them to work again. Another strike broke out, but this time the Grain Unloader Company won. More unloaders were introduced and many jobs were lost.

Though a local affair, the conflict over the grain unloaders became a "question" on a national scale, which was hotly debated in newspapers and periodicals. Most prominent politicians and labour union leaders took sides. The "elevator-kwestie" was regarded as a kind of practical test of opinions about "the machine" and its social implications, which had been taking shape from around 1820 . By the end of the nineteenth century, a virtual consensus had been reached among the leading spokesmen of political parties and interest groups in which technological innovation was acclaimed as a progressive force, while the problems associated with it, such as child labour and accidents with machinery, were attributed to deficiencies in social institutions and laws that could be amended by legislative and technical means. Resistance to modern technology was generally condemned by the leaders of public opinion as "reactionary".

The "elevator-kwestie" shook this consensus. Thousands of workers were prepared to risk their jobs and suffer hunger in order to prevent the introduction of the machine. Most politicians and labour union leaders condemned the strike and stuck to a broadly optimistic view of machinery, but some labour leaders in Rotterdam harbour were not so convinced of the beneficial effects of technological progress after all and supported the strike. In passionate debates with their superiors, they criticized the standard interpretations of mechanization as superficial and impractical, and proposed more adequate analyses and guides to action. The crisis provoked by the introduction of the unloaders therefore exposed, as crises often do, strains and contradictions in the dominant ideology, which had been allowed to slumber in more peaceful times. This makes the "elevator-kwestie" an ideal case for studying the workings of ideology, that is, the relationship between ideas and social action.

2. The emergence of this consensus is discussed in D. van Lente, "Ideology and Technology. Reactions to Modern Technology in the Netherlands I850-I920", European History Quarterly, 22 (I992), pp. 383-4I4. 


\section{THE GRAIN GAME: GROUPS AND INTERESTS IN ROTTERDAM HARBOUR}

The conflict over the grain unloaders was a complicated affair, because many different groups, with diverse interests, were involved in it. In order to understand their reactions to the new machinery, we have to acquaint ourselves with their positions in the trade and the handling of grain, and the explicit and implicit "rules of the game" as understood by the various participants. ${ }^{3}$

The grain trade had been an international affair for centuries. Rotterdam became an important port for grain only after I870, as a consequence of the rapid rise of the Ruhrgebiet, which had the river Rhine as its main connection to the sea and Rotterdam as its main seaport. At the same time, grain production in countries such as the United States, Argentina and the Black Sea area increased tremendously and transportation was facilitated by railways and steamships. In 1872, the access of the harbour to the sea was greatly improved by the opening of a new canal and Rotterdam became the funnel through which grain from all over the world flowed to the almost insatiable Ruhrgebiet. Its position was contested, however, by other ports on the North Sea, especially Bremen, Hamburg and Antwerp, which served roughly the same area. Because bulk goods like grain were usually transported by irregular services ("tramp shipping"), rather than by liner companies with fixed schedules and ports, the routes by which grain reached its customers could easily be altered. ${ }^{4}$

The complications of the trade and transhipment of grain were mainly due to three factors. The first was the nature of the product. Grain is a perishable and very valuable bulk good, and therefore its transportation and transhipment require more than usual care and are closely supervised by both exporters and receivers. Second, as a consequence of changes in harvests, both the demand for grain in the importing countries and the supply from the producing countries vary much more than is the case with other bulk goods. As a result, the grain trade was an unusually nervous and uncertain business. The third factor was the long chain of intermediary persons and institutions between producers and consumers. Because of the high cost of overseas transportation, grain was only shipped in large quantities. Exporting firms bought grain from many different producers and sold it to European importing firms, who in turn sold the grain to flour mills and

3. This account is mainly based on P. Serton, Rotterdam als haven voor massale goederen (Nijmegen, I919), pp. II-49, I23-I24, I54-I80; J. Schilthuis, De praktijk van den wereldgraanhandel (n.p., I9I8), pp. I27-I56; T. van der Waerden, Geschooldheid en techniek (Delft, I9II), pp. 222-225; H. Mol, Memoires van een havenarbeider (Nijmegen, 1980), pp. I06-132.

4. H.A. van IJsselstein, Rapport omtrent de arbeidstoestanden in de Nederlandsche zeehavens (Amsterdam, I9I4), pp. 3, 8, Io. 
local wholesalers. The transportation over sea was taken care of by a shipping firm, which acted by order of the exporters. There were several shipping firms in Rotterdam, many of which also acted as brokers for colleagues in other countries. Inland transportation from the seaport to the importing firm was the responsibility of the importer who delegated this work to a factor, who in turn hired lighters at a shipping office. ${ }^{5}$ Thus it was at the seaport (in this case, in Rotterdam) that the grain changed hands from the exporter to the importer. This involved transhipment, taking samples and weighing.

Prior to the arrival of the pneumatic grain unloaders, the transhipment of grain was done mainly by hand (although some firms used bucket elevators). The shipping firm entrusted this work to a master stevedore, who hired a gang of dockworkers. These men shovelled the grain in baskets which were hoisted on deck by means of a winch. On deck the basket was weighed and its contents were transferred to a bag which was carried on board ship. Here the bag was emptied into a shoot which ended above the hold of the lighter.

The weighing of the grain was of course very important. The importer had to pay the captain, who represented the exporting firms, for the amount of grain he had ordered. If, however, the amount received, as measured by the weigher, was less than the amount ordered (and this was usually the case), the importer could claim a repayment by the exporter. The captain was paid the freight dues for the amount weighed. Before I866, this weighing had been done by sworn officials employed by the city who formed a kind of guild, but this corporation was dissolved in the general trend of liberalization of the economy. After that, weighers, working for private weighing firms, were employed by the importers. This meant, of course, that they were not entirely impartial, and therefore exporters created controlling firms which supervised the weighing in their name.

Work on board the grain ships, like most manual labour in the harbour, was extremely heavy and unpleasant, ${ }^{6}$ and the irregularity of the trade also put its stamp upon the working conditions of the workers. Regular jobs hardly existed and many workers were unemployed for long periods of time. If one had a job, it was likely to mean 24 to 36 hours of continuous labour. Accidents occurred frequently, and medical care and compensation in times of illness hardly existed. Because labourers were easily recruited from the surrounding countryside, wages and working hours were entirely dictated

5. Railways were hardly used since this cost twice as much as transportation by ship: Serton, Rotterdam als haven, p. 34 .

6. H. Spiekman, "De werkstaking der Rotterdamsche bootwerkers", De Nieuwe Tijd (1900), pp. II7-I4O; idem, "Een en ander uit en over de strijd tusschen arbeid en kapitaal in de Rotterdamsche haven", De Nieuwe Tijd (1907), pp. 602-6ro; Algemeene Havenarbeidersvereeniging "Streven naar verbetering", "Een noodkreet der Rotterdamsche havenarbeiders", 3 April I905 (Gemeente-archief Rotterdam). 
by the employers. The master stevedores were especially hated by the workers for their high-handed cruelty. It was estimated that there were about 2,000 grain workers (including weighers and controllers) in Rotterdam harbour in 1905 (estimates about the total number of workers employed in the harbour vary between IO and 14,000 in the years between 1905 and $\left.1914^{7}\right)$. They were relatively well off: their working hours were usually not as long as those of, say, ore workers, and their wages were a bit higher. ${ }^{8}$

A large seagoing vessel usually contained parcels of grain from several exporters to several buyers. Each party had its representatives - weighers, factors and controllers - on board the unloading ship. The unloading procedure usually involved more than a hundred people and looked, in the words of one grain merchant, ${ }^{9}$ like a "seething anthill" (Figure I). The haste and confusion of the procedure offered many opportunities for embezzlement, which were amply used by all parties involved. ${ }^{10}$ Some exporters mixed sand through the grain. Others claimed too high a weight for their parcels and subsequently delayed repayment. Importers instructed their weighers to manipulate the weighing, which was not difficult to do on board a ship that was rolling on the waves and shaking because of its running engines. Many factors were taking too large samples, which they subsequently sold for themselves. Dockworkers of course also took their share, but these were usually small quantities and when found out they went to jail for a month, leaving their families without an income.

Not only was there a conflict of interests between exporters and importers, but also between the importers and the shipping companies. Since the shipowner was paid for the amount of grain delivered, he could not be very happy with being dependent on the tricks of weighers and factors in establishing this weight. And because the harbour-dues were about half of the transportation costs, they wanted to have their vessels available for a new freight as soon as possible. ${ }^{\text {II }}$ The importers, on the other hand, were not in such a hurry. It had taken about three weeks for the grain to arrive from the Black Sea or La Plata, so whether the transhipment took another one or three days did not make much difference to them. ${ }^{12}$ Besides, since the grain trade operated in such a fluctuating market, importers some-

7. Het Volk, I6 November I905; Katholiek Sociaal Weekblad, 26 October I907; Spiekman, "De werkstaking", p. II9; idem, "Een en ander", p. 605; Van IJsselstein, Rapport, p. 7.

8. Spiekman in Het Volk, I6 November i905.

9. D.L. Uyttenbogaard, "Het graantransportbedrijf", in E.O.H.M. Ruempol (ed.), Gedenkboek uitgegeven ter gelegenheid van het 600-jarig bestaan van de stad Rotterdam I328-I928 (Rotterdam, I928), p. 284.

IO. For the following, see Mol, Memoires, pp. I06-II2, I2I-I22; S. van den Berg in De Havenarbeider, I9 May 1906; D.P.M. Graswinckel and L. Ott, Ioo jaar "in granen”. Handel en wandel van het Comité van graanhandelaren (Rotterdam, I973), pp. 30-3I, 5I; and Schilthuis, De praktijk, pp. I43-I44.

II. Serton, Rotterdam als haven, p. 20.

I2. Hoyack in the Nieuwe Rotterdamsche Courant, II May I907. 


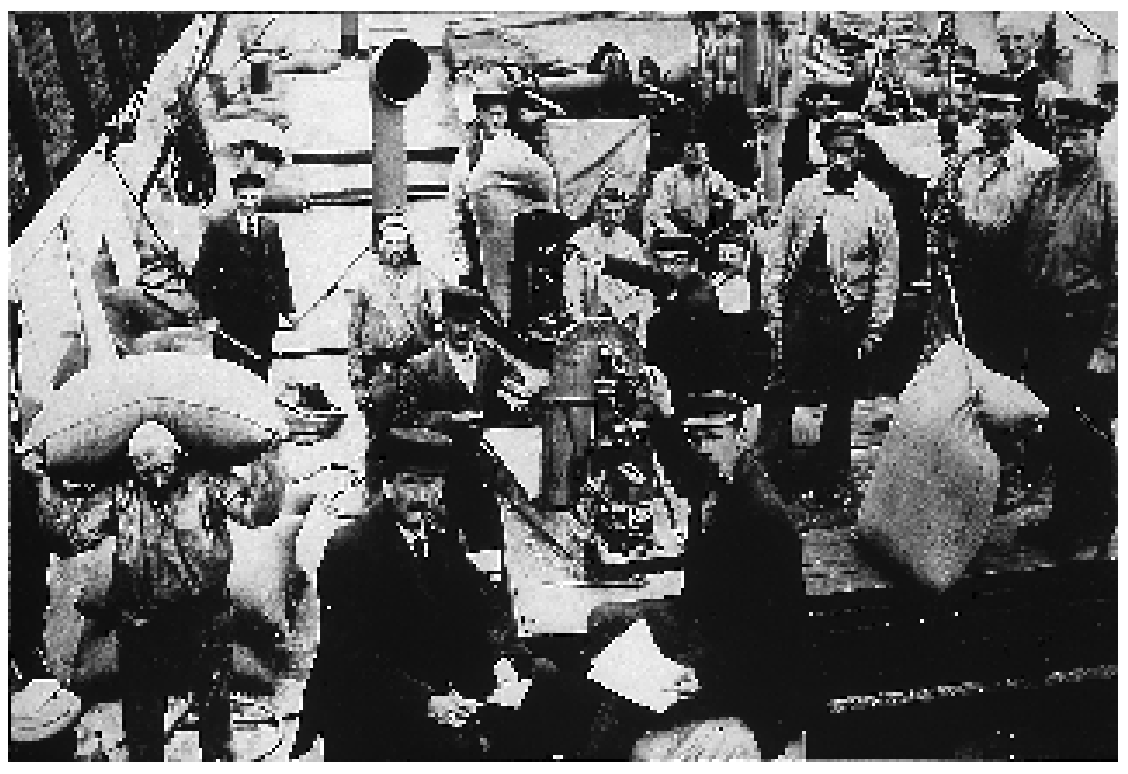

Figure I. Transhipment of grain in Rotterdam around 1900. Anonymous photograph, no date (Gemeentelijke Archiefdienst Rotterdam)

times delayed selling their parcels to the last moment. It could therefore be convenient for them to keep their grain in the hold of the seagoing vessel for another day or two. ${ }^{13}$

The pneumatic grain unloader could simplify these complexities in one stroke (Figures 2 and 3 ). ${ }^{I 4}$ The grain was pumped through four tubes, reaching into the hold of the seagoing ship, into a tank in the tower of the machine. Here it was weighed automatically and released into several tubes, leading to the lighters. The capacity of the machine was about 150 tons of heavy grain per hour. Clearly, the machine would eliminate a lot of manual labour. Only a couple of dockworkers were needed to guide the tubes in the hold of the grain ship, while about seven men operated the engine and moved the floating unloader about in the harbour. The weighers and controllers were not needed any more, the only work left to the factors was administrative and this could easily be taken over by either the Unloader Company or the importers. Transhipment became much more efficient in this way. While it took I26 workers seven to eight days to unload a vessel of 6,000 tons, two unloaders could do the same in two days with fourteen

13. Gemeente-archief Rotterdam, Archief van de Kamer van Koophandel no. 165, "Advies van de Commissie"; Graswinckel and Ott, Ioo jaar "in granen”, p. 50.

14. The following is based upon: Serton, Rotterdam als haven, pp. 39-44; Van der Waerden, Geschooldheid en techniek, pp. 222-225. For technical details see Gemeente-archief Rotterdam, Archief Graan Elevator Maatschappij, no. II. 


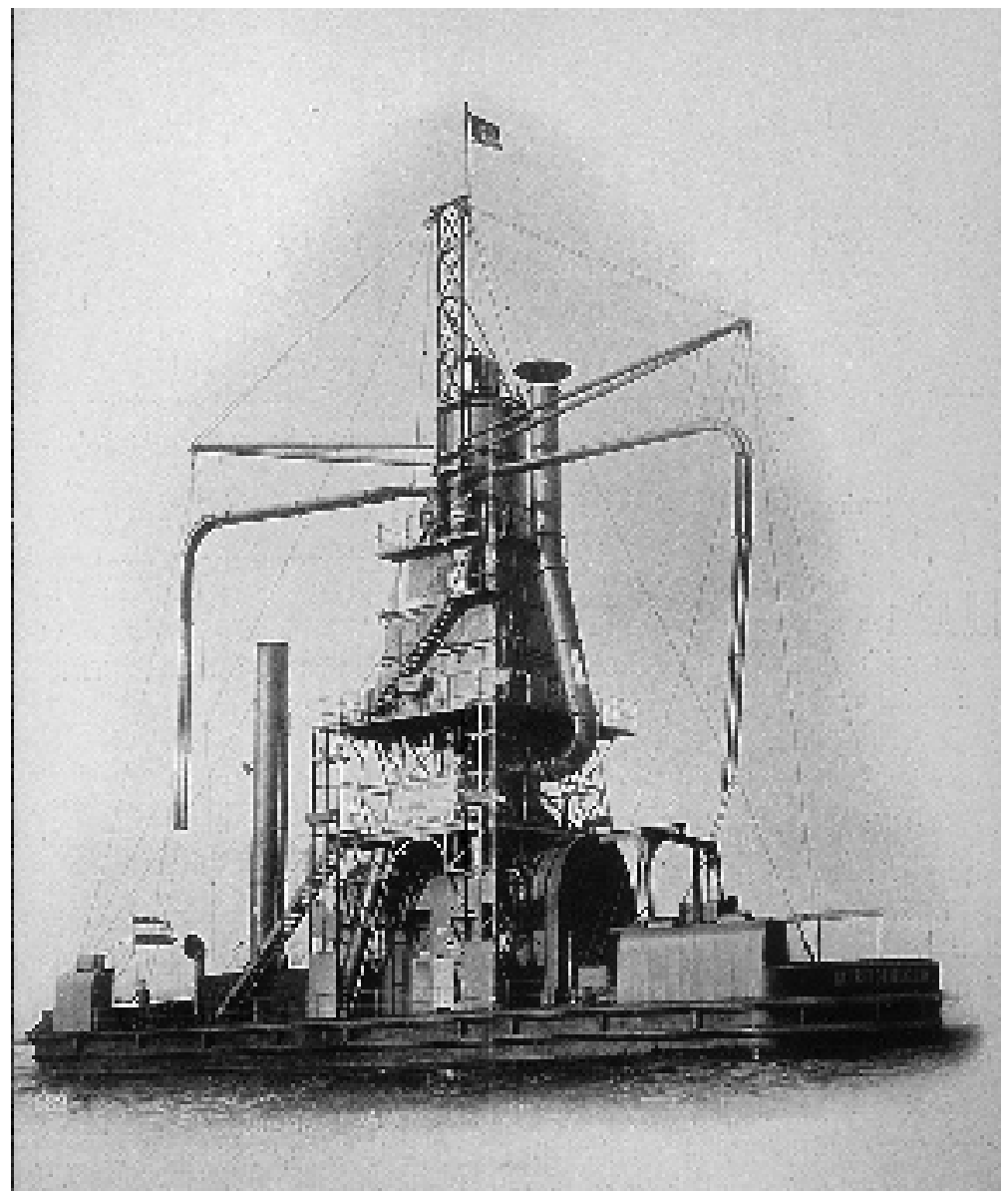

Figure 2. The pneumatic grain unloader. Prospectus by the firm of G. Luther of Braunschweig in Germany (Gemeentelijke Archiefdienst Rotterdam)

men each. ${ }^{\text {Is }}$ This efficiency and the objectivity of the weighing procedure must have appealed especially to the shipowners and brokers.

But the new machines offered many other improvements in the transhipment of grain as well. ${ }^{16}$ Since the tubes required only a small opening of the hatches of the grain ship, the grain was hardly exposed to the open air, so that transhipment could go on regardless of wind and rain. Whereas much grain was lost when it was poured into the open shoot (especially on

I5. Serton, Rotterdam als haven, p. 42.

16. C. A. Cocheret, Het elevator-bedrijf in de Rotterdamsche haven, 1908-1933 (Rotterdam, 1933), pp. I2-I4; A. Voogd, De graanelevators en de gisting in het havenbedrijf (Rotterdam, 1907), pp. 56; J. Schilthuis in Nieuwe Rotterdamsche Courant, 22 May 1907. 


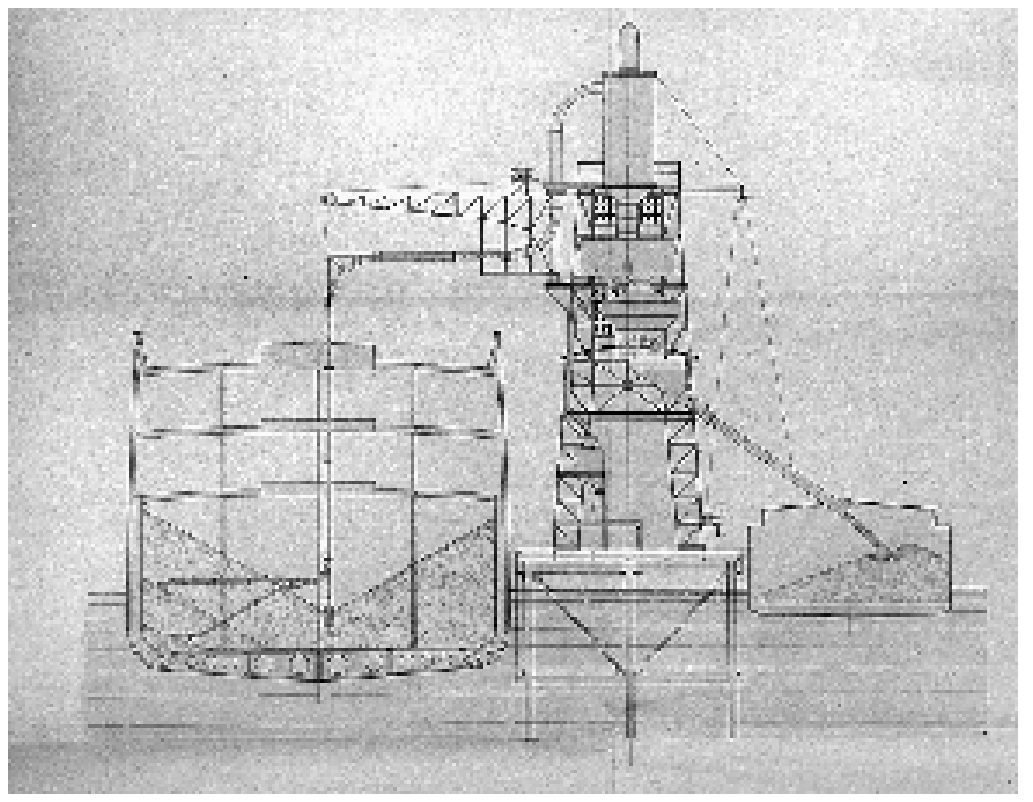

Figure 3. The pneumatic grain unloader. Drawing by the firm of G. Luther (Gemeentelijke Archiefdienst Rotterdam)

windy days and when the shoot was in an almost vertical position or ended high above the lighter, as was the case when large vessels were unloaded), this could not happen with the unloader. ${ }^{17}$

\section{ENTER THE MACHINE: THE FIRST STRIKE ${ }^{18}$}

The first initiative to introduce pneumatic grain unloaders in Rotterdam harbour came not from shipowners and brokers, as we might have expected, but from an organization of German importers, the Verein deutscher Handelsmüller. A delegation of this organization visited Rotterdam in I9OI, in order to propagate the machine. Pneumatic grain unloaders had been in use

17. A possible advantage was that the machine cleaned the grain automatically by removing dust and other light admixtures. This was, of course, not in the interest of the exporters, who would have to make greater repayments. Therefore the unloader had a device to mix the dust again with the grain before weighing. See Serton, Rotterdam als haven, p. 4I.

I8. Good accounts are, from the point of view of the employers: Cocheret, Het elevatorbedrijf, Voogd, De graan-elevators and Uyttenbogaard, "Het graantransportbedrijf", and two anonymous articles in the newspaper De Nieuwe Nederlander, that also appeared in De Maasbode, I2 and I4 November 1905; from the point of view of the workers: S. van den Berg, De elevator-kwestie. Haar verloop en hare betekenis voor de arbeiderswereld (Amsterdam, 1906); $\mathrm{H}$. Mol, Memoires; idem, "Uit het Rotterdamsche havenbedrijf", Socialistische Gids (1920), pp. 545-549, 655-662; and J. Brautigam, Langs de havens en op de schepen. Herinneringen (Amsterdam, 1956). 
for some time in the London docks and recently also in Hamburg, Bremen, Genoa and New York. ${ }^{19}$ The German merchants said that Rotterdam should not lag behind and in an address to the Rotterdam Chamber of Commerce, they spelled out the advantages of the machine. They pointed especially to the speed of the transhipment, the objective weighing procedure and the possibility of cleaning the grain, since this would spare them the payment of import duties over the extra weight of dust and sand..$^{20}$ The enthusiasm of the importers was influenced by the trouble they were having at that time with Russian and Rumanian exporters, whom they accused of mixing a lot of dirt through the grain and having their controllers manipulate the weighing. Four years later, in 1905, the German and the Dutch importers decided to create a charter that would be imposed upon the exporters on the Black Sea, to rule out these irregularities. ${ }^{21}$ Apparently this agreement was successful, for complaints about grain from the Black Sea areas did not recur. Thereafter, the German importers lost their enthusiasm for the grain unloaders and even came to oppose them, as we shall see.

The Chamber of Commerce was not impressed by the arguments of the Germans, but it did recommend the introduction of the machine, because the automatic weighing and the saving of labour costs would attract business to Rotterdam harbour. ${ }^{22}$ The records show no great concern on the part of the Rotterdam entrepreneurs about lagging behind other ports with regard to unloading equipment. This is understandable, because even in London, Hamburg and New York, most work was still done by hand. New York, for example, though far behind Hamburg in port equipment, had a much better reputation for quick dispatch, because its dockers worked longer hours and at higher speed. ${ }^{23}$ The Chamber of Commerce recommended that the city of Rotterdam introduce grain unloaders as it had done with electrical cranes, but apparently nothing came of this. ${ }^{24}$ Then the "Neder-

19. Reports in Gemeente-archief Rotterdam, Archief Graan Elevator Maatschappij, no. I.

20. See also Gemeente-archief Rotterdam, Archief Nederlandsche Veem, notulen bestuursvergadering, 8 August 190I. I owe this reference to Hugo van Driel.

2I. J.C.A. Everwijn, Beschrijving van handel en nijverheid in Nederland ('s-Gravenhage, I912), pp. 643-646; Schilthuis, De praktijk, p. I43.

22. Gemeente-archief Rotterdam, Archief Kamer van Koophandel, no. II3, letter no. I65, advice of the committee of the Chamber of Commerce about the importance of grain unloaders for the Rotterdam harbour.

23. J. Lovell, Stevedores and Dockers. A Study of Trade Unionism in the Port of London (London, 1969), p. 28.

24. In the minutes of the municipal council and in the archives of both the municipal council and the city administration the whole conflict is hardly mentioned at all, which shows that local politicians regarded this as an affair between employers and workers. See Gemeente-archief Rotterdam, Handelingen van de Gemeenteraad, 1900-1907; Archief Gemeenteraad en college van Burgemeester en Wethouders, secretarieafdeling Algemene Zaken en kabinet van de burgemeester, nos. 5698, Index op uitgaande stukken van de burgemeester; II4I, Index op notulen B. en W. 1902-1922; 674, Notulen van geheime raadsvergaderingen I88I-1907. 
landsche Veem", a storing and shipment firm, took the initiative. ${ }^{25}$ It turned out to be hard to raise capital for a grain unloader company, as neither the German nor the Dutch importers would risk any money in it. The quick dispatch and the objective weighing were not really in their interest, as was shown in the previous section. When in March 1904 the Grain Unloader Company was eventually founded, it was financed largely by Rotterdam shipowners and brokers (three factors and one stevedore company also taking some shares), whose most important motive was quick dispatch. ${ }^{26}$ The capital raised was sufficient for only two machines ${ }^{27}$ and it was decided to buy floating unloaders, which could be moved all round the ship in the new Maashaven.

Both the Chamber of Commerce and the new Unloader Company anticipated trouble with workers, master stevedores and factors, all of whom were threatened by the machine. The Company decided to cooperate as much as much as possible with the master stevedores and factors, in order to prevent them from taking sides with the workers. They offered to put the machines at their disposal and give them a share in the profits. In other words, they wanted to integrate the machine into the existing system of transhipment. As for the dockworkers, previous actions against new machinery must, the Company thought, have made it clear to them that resistance was completely ineffective. In the long run, the new machinery would attract more freight to the harbour, which would create sufficient employment for them all. ${ }^{28}$

The Rotterdam dock workers had indeed some experience with collective action. ${ }^{29}$ In 1882, a new bucket conveyor for grain had been destroyed by fire after a strike..$^{30}$ In I889, inspired by the great strike in the London docks, the Rotterdam dockers struck for the first time on a massive scale and

25. For its motives, see H. van Driel, "Innovatie in de overslagtechnologie te Rotterdam", in idem (ed.), Ontwikkeling van bedrijfskundig denken en doen: een Rotterdams perspectief (Rotterdam, I993), pp. 2I-23 and idem, Vier eeuwen Veembedrijf (2nd ed., Rotterdam, I992), pp. 98-IOO.

26. Scheepvaart, 22 July I905.

27. Cocheret, Het elevator-bedrijf, pp. 20, 50. That a lack of capital was the main reason for buying only two machines is not explicitly stated in the sources, but it may be inferred from the arguments in the letter of I February 1904, in the archives of the Graan Elevator Maatschappij at the Gemeente-archief Rotterdam, no. $2 \mathrm{~A}$, and from the arguments put forward later on by the company.

28. Gemeente-archief Rotterdam, Archief Graan Elevator Maatschappij, no. 2A, letter of I February 1904 .

29. Spiekman, "De werkstaking", pp. II7-I40; H. Smits, De Nederlandsche arbeidersbeweging in de negentiende eeuw (Rotterdam, I9O2), pp. IOO-IOI, I52-I55, I95-200; Mol, "Uit het Rotterdamsche havenbedrijf"; for strikes against machinery see R. Van 't Wel, Technologie en protest in de Rotterdamse haven (unpublished master's thesis, Erasmus University, 1986), pp. 66-85.

30. This "sad experience" was referred to by the Chamber of Commerce in its advice, cited in note 26 . Whether this was a case of arson, and if so, by whom, is not clear in the sources. See also Graswinckel and Ott, Ioo jaar “in granen”, pp. 24, 37; W.A.H. Crol, Een tak van de familie Van Stolk. Honderd jaar in de graanhandel, I847-1947 (Rotterdam, 1947), p. 24; Gemeente-archief Rotterdam, Politie-archief, no. I38, year I883. 
achieved a raising of wages. In 1896 the introduction of electric cranes provoked a strike by the oreworkers which failed, and in 1900 a great strike for shorter working hours and better working conditions also failed. There were short and unsuccessful actions after the introduction of new transport machinery for the transhipment of coal in 1903 and 1904. After both these strikes many jobs had been lost.

The pattern of these actions was always the same, and very similar to that in other great European ports around 1900. They came suddenly, were hardly planned, exhibited a remarkable solidarity between different categories of workers, and never lasted longer than two weeks, usually much less. Labour unions hardly existed. The prominence of casual labour, inducing a sense of individualism, the constant competition for jobs, and the poverty of the men - all these circumstances stood in the way of permanent organizations with ample strike-funds. ${ }^{31}$ When the workers took action, therefore, they tried to overwhelm the employers by a massive and sudden attack what syndicalists called "direct action". The success of some of these actions, like the one in I889, confirmed their faith in this tactic. During a strike, some organizations would be set up, which were joined by hundreds or even thousands of workers, only to shrink and often disappear soon afterwards. If any concessions were granted by the employers (as happened in I889), these were silently withdrawn in succeeding years. During a strike, the employers could easily break the resistance of the workers by recruiting men from the villages in the region or from other ports, like Hamburg and London. ${ }^{32}$

The building of the grain unloaders took more than a year. In July I905 they were finished and in August the first grain ship was unloaded by machine (Figure 4). Unfortunately for the Unloader Company, the weighing apparatus did not work. Because no provision had been made to break the fall of the grain into the weighing scale, its indications were far too high. ${ }^{33}$ Since this could not be repaired quickly enough, the Company had

3I. In the Netherlands as a whole, "modern unionism", meaning strong and permanent organizations, making very selective use of the strike weapon, was still weak. In i9I4, for example, only II per cent of the Dutch workers belonged to a union. Syndicalism was still popular, especially among casual workers. See B. Altena, "Zu den Wirkungsbedingungen des niederländischen Sozialismus I870-I9I4", in H. Lademacher and W. Mühlhausen (eds), Freiheitsstreben, Demokratie, Emanzipation. Aufsätze zur politischen Kultur in Deutschland und den Niederlanden (Münster, I993), pp. 279-280.

32. Mol, "Uit het Rotterdamsche havenbedrijf", pp. 527, 530, 538; T. Jansen, "De wil der bazen regelt het werk'. Havenarbeiders rond 1900 in Rotterdam en Amsterdam”, in J. Giele et al. (eds), Jaarboek voor de geschiedenis van socialisme en arbeidersbeweging in Nederland (Nijmegen, 1979), pp. 54-56, 80-87; F. Broeze, "Militancy and Pragmatism. An International Perspective on Maritime Labour", International Review of Social History, XXXVI (1991), pp. 169, 176, I84, I94; Lovell, Stevedores and Dockers, p. 97; M. Grüttner, Arbeitswelt an der Wasserkante. Sozialgeschichte der Hamburger Hafenarbeiter I886-19I4 (Göttingen, 1984), pp. 245-25I.

33. This was ascribed to the hasty installation of the machines, whose delivery had been delayed. It is somewhat surprising, since the German firm Luther had delivered machines with good weighing apparatus before. The GEM used hand weighing apparatus at least until the end of the 


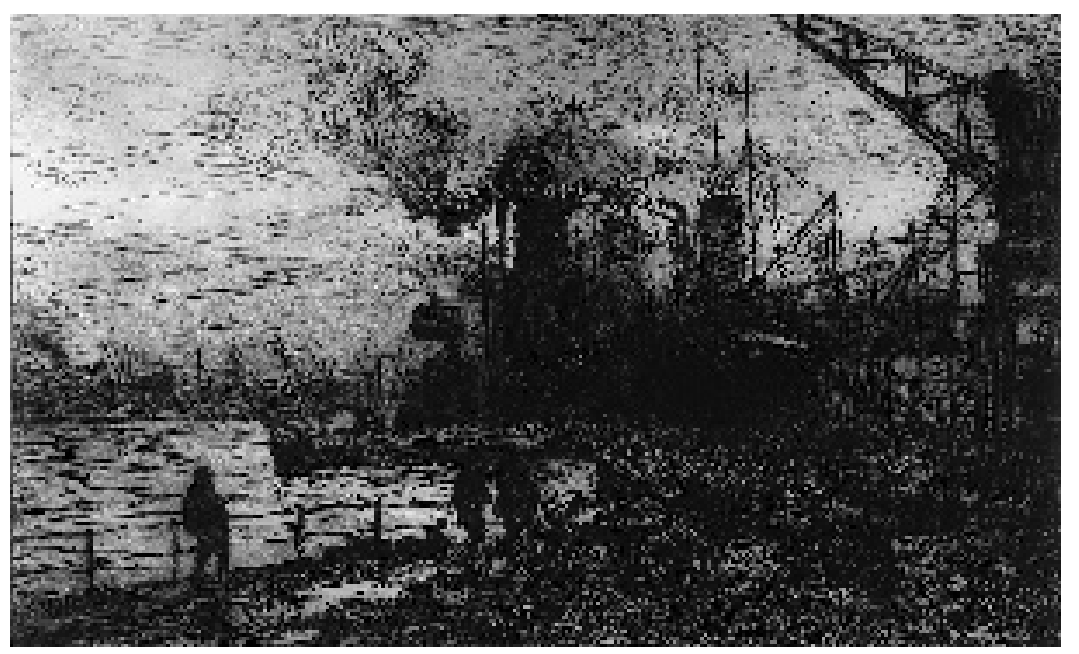

Figure 4. Maashaven (the main grain harbour) as seen from the east. Etching by J.H. van Mastenbroek, I9I5 (Gemeentelijke Archiefdienst Rotterdam)

to install a container on the deck of the ship, from which large batches of grain could be weighed by hand in a weighing apparatus (a much faster procedure than the traditional manner of weighing). The installation of this apparatus took six weeks.

The spectacle of the iron monsters at work had clearly shocked the workers. During the six weeks in which the machines were idle, the weighers, controllers, factors and master stevedores - the groups whose work the machine threatened most to eliminate - all created their own organizations. At a meeting held on 13 August, A.C. Wessels, the social-democratic leader of the largest dockers' union, AHAV, tried in vain to unify these organizations and to restrain their demands. Some favoured "direct action", others a more limited strike. The meeting ended in turmoil when a well-known coal worker and agitator, Ooykaas, wildly accused several leaders of vagueness and evading the real issue. ${ }^{34}$

The new organizations put forward high claims: no workers should be fired and the unloaders should only be used as a supplement to unloading by hand. The Company offered a io per cent raise in wages in exchange for acceptance of the machines and the introduction of two

conflict in 1907. See printed letter to German importers, dated 23 March 1907, Gemeente-archief Rotterdam, Archief Graan Elevator Maatschappij, no. 55.

34. De Maasbode, 16 August 1905; Rotterdamsch Nieuwsblad, I5 August 1905; Nienwe Rotterdamsche Courant, I4 August 1905. Ooykaas's boss, Van Beuningen, also describes him as a hot-tempered man, who called himself a Christian-anarchist (which places him close to Van den Berg, a much more interesting figure, whom we will meet presently). See Van Beuningen's manuscript autobiography, at the Gemeente-archief Rotterdam, handschrift no. 326, pp. $28-29$. 
new ones. It could not of course guarantee that the same number of workers would find work in the transhipment of grain. These offers were unacceptable to the workers' organizations, but when all was said and done, only the weighers, who were the best organized of all, were prepared for action. They called a strike on 3 November and the next day not one of the 450 weighers appeared on the ships. The controllers immediately joined the strike. The personnel of the Grain Unloader Company continued to work and several ships were unloaded by hand during the next few weeks: some captains had the grain transhipped unweighed, because they could not afford to leave their vessels idle for an unknown length of time. The costs of the lighters and the weighing that had to be done later would probably have to be paid for by the importers, who were expected to challenge this procedure in court. ${ }^{35}$ It is impossible to tell how many workers besides weighers and controllers struck and how large a part of the grain trade was held up, but it is clear that the weighers by their concerted action had created serious stagnation and caused a panic among the importers, especially those in Germany.

When the German importers heard about the strike, they immediately sent a committee to the Rotterdam mayor, who refused to interfere in the conflict. Then the importers negotiated with their factors and the weighers and reached an agreement with them: during the next six months they would only accept grain that had been weighed in the traditional way. This meant that the transhipment would be as slow as before, even if the pneumatic unloaders were used. Thus the advantages of the new machines were wiped out and the weighers had won a fast victory. On 2I November they were at work again. The Unloader Company was forced to lay up its machines.

The action of the German importers is not difficult to understand. To them, the strike came at a very unfortunate moment: just before the onset of winter, when the river Rhine was often frozen over, making transportation impossible. On I March, the German tariff on grain would be raised and, therefore, they had no time to lose. Since the two unloaders could tranship only io per cent of all the incoming grain at most,$^{36}$ the importers would be dependent on the weighers for some time to come and had no choice but to negotiate with them. Besides, the traditional manner of weighing was advantageous to the importers, as was argued in the previous section. In Rotterdam, said one observer, "the sparrows are squeaking from the rooftops" that the unloaders, once their weighing apparatus functioned normally, would weigh only too accurately for the importers. The weighers,

35. See the article in De Nieuwe Nederlander, cited in note 18, and reports in De Maasbode during the strike, about ships being unloaded.

36. Voogd, De graanelevators, p. II. 
who worked for the importers, used to write up far lower weights than the importers were receiving (up to 20 per cent according to some). ${ }^{37}$

While understandable, the agreement was probably illegal. The weighers were employees of weighing firms, the most prestigious of which were employed by the Committee of Dutch Grain Merchants. The German importers had completely bypassed these firms and their Dutch colleagues, and this explains why most Dutch grain merchants refused to sign the contract. They were rather indifferent to the unloader, but they could not accept that "their" weighers were, together with the Germans, imposing the order of the grain trade. ${ }^{38}$ Another legal problem was whether the grain importers had the right to determine the way of delivery. Their main argument, that they owned the grain, was not very strong. It was the captain (hence the shipowner) who, on the basis of the bill of lading, determined the manner of transhipment. Many of these charters included the clause that transhipment should proceed "as fast as steamer can deliver". This could be taken to imply delivery by machine, but whether this had to include weighing was a moot question, which was only decided in court years later when it was not disputed any more.

In the meantime, the Unloader Company was at a loss to know what to do. It realized that it would have been better to introduce twelve unloaders instead of only two, so that the resistance of weighers, workers and factors could have been swept away at one stroke. ${ }^{39}$ The Company considered buying more machines, ${ }^{40}$ but nothing came of this, probably because it would have been hard to obtain capital at this difficult juncture. It also considered selling the machines, and they were even offered to Hamburg. Finally, in April 1906, the master stevedore Thomsen hired the unloaders for half a year. He offered the workers to keep as many men employed as if transhipment took place by hand; because the machines would do most of the work, the workers would receive half of their present wages; and during the next three years, no new unloaders would be introduced ${ }^{4+}$ The AHAV urged the workers to accept this offer with certain conditions, ${ }^{42}$ but the assembled unions turned it down. They said the dockers did not want

37. Wibaut in Bondsbanier (Rotterdamsche Bestuurdersbond), I June 1907, cited by Cocheret, Het elevator-bedrijf, p. 6o. Cf. ibid., pp. 65, 72, II9; Voogd, De graanelevators, p. 27; Mol, Memoires, pp. I07-IO8.

38. Cocheret, Het elevator-bedrijf, p. 48. In fact, the position of the Dutch importers was very awkward. They had, after long negotiations, reached an agreement with their German colleagues about the Black Sea charters, which they did not want to jeopardize. The unloaders were not really in their interest: Graswinckel and Ott, I0o jaar “in granen”, pp. 49-50.

39. Ibid., p. 48.

40. Gemeente-archief Rotterdam, Archief Graan Elevator Maatschappij archive, no. 3 has several quotes dated February and March 1906.

4I. Gemeente-archief Rotterdam, Archief Kamer van Koopkandel, no. II8, printed letter of 3 April 1906 (no. IOo).

42. De Havenarbeider, I4 and 21 April 1906. 
to work less if that cost them half their wages. They were afraid Thomsen was trying to establish a monopoly on grain transhipment and that he would in the end introduce more machines and fire the workers. ${ }^{43}$ Thomsen could therefore not find any men to work for him, and the contract was not renewed.

\section{THE DEBATE}

The first working men's association to react to the coming of the new machines was the Algemeene Havenarbeidersvereeniging (General Dockworkers Association), or AHAV, the Rotterdam section of the socialistoriented Nederlandsche Scheeps- en Bootwerkersbond. After the failed strike in 1900 it had shrunk to only a few hundred members, but during the conflict over the grain unloaders it grew again: in 1907 between I,600 and 2,000 dockworkers belonged to it. ${ }^{44}$ Its weekly paper De Havenarbeider (The Dockworker), in the beginning of April 1904, reviewed the innovations that had recently been introduced in the harbour. All of these had eliminated labour. Reminding the workers of the fruitless attempts of the English machine breakers to eliminate textile machinery almost a century earlier, the paper urged the workers not to try to destroy the machines. The mechanization of work is part of the inevitable progress of society, it wrote. Eventually, in a socialist society, this machinery would be employed for the benefit of all. Before such a society was realized, the workers should unite to claim their share in the advantages of mechanization, that is, shorter working hours and higher wages. The paper warned that as long as the Rotterdam labourers remained indifferent towards the union, they would lose every battle with the employers.

The problem of the grain unloaders was therefore discussed in terms of the common socialist theory of technology, which held that technological progress was the main contribution of capitalism to human development and should therefore not be resisted:45 "Our watchword should not be: away

43. Toenadering I/4, I7 May 1906; De Volksbanier, 26 April 1906; De Havenarbeider, I4 and 21 April 1906. One must remember that master stevedores and dockworkers were often very hostile to one another. The workers distrusted these employers more than any other group. See $D e$ Havenarbeider, 2I April 1906; T. Jansen, “'De wil der bazen””, pp. 3I-37.

44. The estimate of 1,600 is from the Roman Catholic journal Katholiek Sociaal Weekblad, 26 October 1907, while Spiekman claimed 2,000 "regularly paying members" in De Nieuwe Tijd (1907), p. 740.

45. See also the opinion of the German Hafenarbeiter, 20 July 1907. It called this battle against a machine that had already been established in Hamburg for a few years "eigenartig" and not "volkswirtschaftlich richtig", but hoped that the strikers would be successful because this would strengthen their organization to such an extent that in the future they would not have to strike against new machinery (but could claim its advantages, it implied). See Gemeente-archief Rotterdam, Archief Graan Elevator Maatschappij, no. 9A. Grüttner, Arbeitswelt an der Wasserkante, p. 47, cites the German labour union leader Döring, who used stronger language to condemn the 
with machinery, but away with the capitalists and capital to the workers. ${ }^{36}$ One prominent social-democratic leader even argued that it was in the real interest of the working classes that strikes against new machinery were lost. ${ }^{47}$ Therefore, the AHAV found support for its position not only from socialdemocratic party and labour union leaders, such as F.M. Wibaut, ${ }^{48}$ L.M. Hermans, N. van Hinte and J. Oudegeest ${ }^{49}$ but even from more radical socialists such as $\mathrm{H}$. Kolthek, ${ }^{50} \mathrm{~F}$. Domela Nieuwenhuis, ${ }^{5 \mathrm{I}}$ and H. Gorter. ${ }^{52}$ This official point of view was not shared by all members of the AHAV. At a meeting on 30 August, a majority voted in favour of a strike against the unloaders. ${ }^{93}$ Nevertheless, the AHAV condemned the strike when it broke out two months later, although it decided to support the workers financially, out of solidarity. In the meantime it constantly urged the men to join the organization.

The articles in the Havenarbeider suggest that the AHAV leaders endorsed the official socialist doctrine, but felt they had to support the strike if they did not want to lose the respect of the workers. An important factor in taking this position was probably that the strikers had found an unexpected ally in the person of Hendrik Spiekman, the most popular social-democratic leader in Rotterdam. In response to a survey held a few weeks before the strike by AHAV chairman Wessels, Spiekman had said that if the workers had a real possibility to block the introduction of a machine that would seriously harm their interests, they should do so. In a series of articles in the social-democratic newspaper Het Volk he defended this position, which, he realized, would be regarded as "reactionary" by most socialists. ${ }^{54}$ Often, Spiekman said, the introduction of machinery cannot be avoided because of foreign competition. It can also be an improvement for the workers, if it lightens the burden of labour. If mechanization proceeds gradually, the loss of jobs will be compensated for by the fact that new firms and new products and markets create more work. But in the case of the grain unloaders none of these conditions existed. Because of their rapid introduction,

Rotterdam strike, calling the struggle against the machine - this "Errungenschaft der Kultur und der Technik" - "etwas Unverständliches, eine Barbarei".

46. Recht Voor Allen, 25 June 1888.

47. De Nieuwe Tijd (1908), p. 870.

48. F.M. Wibaut, "De machine", De Kroniek, 2 December 1905.

49. Cocheret, Het elevator-bedrijf, p. 44.

50. De Havenarbeider, I4 October I905.

5I. Van den Berg, Elevator-kwestie, p. 9 and Mol, "Uit het Rotterdamsche havenbedrijf", p. 545, both reporting on a meeting of the Socialist propaganda club, at which Domela spoke. He is cited similarly by the entrepreneur Van Beuningen, who was also present at this meeting, in his manuscript autobiography: see Gemeente-archief Rotterdam, manuscript no. 326, p. 27.

52. Cited in Voorwaarts. Weekblad voor de Arbeiderspartij in Zuid-Holland, 4 November 1905.

53. Van den Berg, Elevator-kwestie, p. I3; Mol, Memoires, p. 176.

54. Het Volk, I6, I8 and 2I November 1905. 
workers losing their jobs would not easily find new work. The competition argument did not hold, according to Spiekman, because during the last few years, Rotterdam harbour had, without machines, grown much faster than its competitors. With its large supply of labour, it could easily handle a further increase in transhipments. The only motive of the Unloader Company could therefore be to appropriate the income of workers, master stevedores, factors and weighers, whose work would be made superfluous by the machine, and this was unacceptable. Only if the machines were used merely to speed up transhipment, while employing the same number of workers, did Spiekman have no objections.

Spiekman was immediately criticized by his comrades for this departure from socialist doctrine and he found no support at all from other socialdemocratic leaders. Wessel replied in Het Volk that mechanization made transhipment so much cheaper, that all ports would eventually be forced to introduce machinery. The argument that Rotterdam had outstripped other seaports in recent years, in spite of the fact that elsewhere unloaders were used, did not impress him: when more machines are introduced, he said, the effects will soon make themselves felt. ${ }^{55}$

Why did Spiekman take this unusual position? Like other "modern" union leaders, he had pleaded time and time again for organization (he himself was a compositor, one of the best organized trades). He was exasperated by the fact that unions built up during strikes disintegrated shortly afterwards. ${ }^{56} \mathrm{He}$ therefore felt the urgent need to support and consolidate the organizations which had emerged during this conflict. This could only be done by bringing them together in a union like the AHAV, but since Wessels and other social-democrats could not convince the workers with vague slogans like "Here with the machine", he attempted to reconcile the aims of the strikers with socialist doctrine. ${ }^{57}$

The orthodox Calvinist dockworkers' union "Toenadering" was founded in I900 by members of the Nederlandsche Scheeps- en Bootwerkersbond who refused to attend meetings on Sundays. ${ }^{58}$ It was closely connected with "Patrimonium", the national organization of orthodox Protestant workers,

55. Ibid., 28 November 1905 .

56. Spiekman, "De werkstaking", pp. II7, I24, 138 .

57. Spiekman's position illustrates nicely the conflict between militancy and pragmatism, that was typical of maritime labour organizations all over the world in this period, according to Broeze, "Militancy and Pragmatism", p. I78.

58. See the small memorial volume Gedenkboekje uitgegeven ter herinnering aan het 25-jarig bestaan van "Toenadering", afdeeling Rotterdam van den Nederlandschen Bond van Christelijke Fabrieks- en Transportarbeiders Io juli I 1900 - Io juli I925 (n.p., n.d. [1925]) and the weekly paper Toenadering, which started to appear in February 1906; both are at the International Institute of Social History in Amsterdam. 
and its opposition to the great railway strike in 1903 had earned Toenadering a bad reputation with the socialists. ${ }^{59}$ At its foundation it claimed to have about I,000 members, ${ }^{60}$ but by 1905 this number had probably dwindled to a few hundred. ${ }^{61}$ The name of this union, which means "rapprochement", proclaimed its aim. It rejected the principle of class conflict and aimed at negotiations with the employers. Early in 1905 it sent a delegation to London to inquire about the new machinery. Immediately after its return, the union started to negotiate with the employers. In August 1905 it proposed that the unloaders be used only to tranship loads over 500 "last" and that wages be increased. Although Wessels of the AHAV found this a good proposal, the dockworkers' organizations turned it down. The employers simply ignored it.

Like the AHAV, Toenadering approached the problem of the unloaders from a general theory about technology and society. This theory clearly and explicitly derived from Abraham Kuyper, the leader of the orthodox Calvinists in the Netherlands and one of the most influential politicians at the time. ${ }^{62}$ Kuyper believed that man's dominion over nature was a divine command. Its achievement through science and technology was made possible by God's greatest gift to man, his ingenuity. Therefore, technological innovations should be accepted. The problems that often accompany these innovations were not to be blamed upon the technologies themselves, but upon the liberal-capitalist system. As with all problems in the modern world, these would only be overcome if society returned into the fold of orthodox religion. In practice this meant, for example, that labour relations should be regulated by agreements reached in corporate bodies consisting of employers and workers.

On the basis of this doctrine, Toenadering worked out a position that was much more radical than Kuyper intended. Its basic assumption was that the harbour was a working community in which each participant had inviolable rights. The introduction of machinery that had a great impact upon the workers should therefore be based upon an agreement between all

59. See, for example, De Havenarbeider, I4 January 1905.

60. Gemeente-archief Rotterdam, collection "pol. vakbonden alf.", bulletin 1900. The relatively large size of this union can be explained by the fact that many Rotterdam workers were recruited from the villages to the south and south-east of Rotterdam, which is part of the Dutch "Bible Belt".

6I. According to Mol, "Uit het Rotterdamsche havenbedrijf”, p. 542, Toenadering was, with only 70 members after the great strike of 1900 , still the largest union in the port. The Roman Catholic newspaper Katholiek Sociaal Weekblad (26 October 1907) estimated its membership in 1907 at 200 ; in 1908 it was I50 according to A.J. Teychiné Stakenburg, SVZ stand van zaken. Een halve eeuw arbeidsverhoudingen in de Rotterdamse haven 1907-1957 (Rotterdam, 1957), p. 19.

62. See especially Toenadering, I6 May 1907, 28 November 1907. About Kuyper's ideas, see Van Lente, "Ideology and Technology", pp. 393-398 and H.E.S. Woldring, "De sociale kwestie - meer dan een emancipatiestrijd", in C. Augustijn et al. (eds), Abraham Kuyper. Zijn volksdeel, zijn invloed (Delft, 1987), pp. I23-I45. 
persons involved. But in fact, said Toenadering, in the docks "might is right". The unloaders served exclusively the needs of the employers. The socialists, according to Toenadering, only wanted to reverse the present power relationship between workers and employers, which would obviously lead to new forms of repression. The only true solution was creating order, not on the basis of power, but upon the divine law that God by His grace had inscribed in every human heart. For Toenadering this meant the acceptance of the grain unloaders, for like every new technology they were to be considered gifts from God. It also meant acceptance of the authority of the employers, who had received this reponsibility from God. But it meant as well that benefits of the new technology should accrue to the whole harbour community, not just to the employers. The worker could not simply be dismissed from his job, for God had granted him the right to "eat his bread by the sweat of his brow". Since the employers had not responded to the reasonable proposals made by Toenadering in August, it considered the strike of the weighers justified. It opposed "for the time being" a general strike, and pleaded for negotiations between workers and employers. ${ }^{63}$

This position was much more radical than that of Patrimonium and that of Kuyper himself. The newspaper Patrimonium stressed the inevitability of technological progress and supported Toenadering's proposals for negotiations, but ignored its endorsement of the strike. It condemned the idea of a general strike as "anarchist", while Toenadering had only dismissed it "for the time being". When Patrimonium wrote that the unloaders would probably not cause much unemployment because trade in the docks was increasing, it drew a critical reply from a Rotterdam member, who wrote that machinery would certainly replace much labour in the future and that the employers, by not taking the interests of the workers into account, deserved a strong reply. ${ }^{64}$ Kuyper himself chose to ignore the strike in his daily editorials in De Standaard, but ten years earlier he had, on the occasion of the strike against the introduction of electrical cranes, written that actions like these were useless. ${ }^{65}$ The men of Toenadering therefore found very little support from national orthodox Protestant leaders.

The Roman Catholic dockworkers also had a small union, called "Kardinaal Manning", with at most 200 members in $1907 .{ }^{66}$ It was the dockworkers'

63. Patrimonium, i6 November 1905.

64. Ibid., I2 and in October 1905.

65. De Standaard, 25 March 1896.

66. Kardinaal Manning did not have its own newspaper. Its leaders published in De Volksbanier, which for our period is only preserved at the International Institute of Social History in Amsterdam up to June 1907. It is my main source for the following statements. The number of members mentioned here is taken from the Katholiek Sociaal Weekblad of 26 October 1907. The same article says that 60 members appeared at a meeting in June 1906; a priest claimed in De Volksbanier, 7 June 1906, that the organization should have at least I,000 members. 
section of the Rotterdam department of the Roman Catholic People's League (Roomsch Katholieke Volksbond). Initially, Kardinaal Manning had not officially backed up the strike, but its men had helped the strikers, for example by distributing their manifestos, ${ }^{67}$ and in the end the union, like Toenadering, came to support the strike. The chairman of the department, F.J.B. van Rijswijk, explained this position in a long article in November 1905, after the strike had ended. His arguments were often repeated during the following months.

Van Rijswijk's position was far removed from the official technological optimism of Roman Catholic leaders, which was very similar to Kuyper's point of view. It was closer to Spiekman and Toenadering. Like Spiekman, he questioned the necessity of introducing the new machines. The Rotterdam harbour, he argued, is internationally known for its cheapness and quick dispatch and there has never been a lack of workers. The introduction of the unloaders is therefore not in the interest of the harbour as a whole but only in that of the employers. Their argument that the new equipment will attract more work is spurious, because other harbours, like Antwerp, will be forced to follow suit, thereby increasing competition. Although he did not say so explicitly, Van Rijswijk does not seem to have rejected the unloader as such, for he wrote that had the unloaders been introduced twenty years before, when the grain trade started to grow, they could have been easily integrated into the transhipment system. But as it happened, the growth of the grain trade had led to a tremendous increase in the number of workers, who were now dependent upon the transhipment of grain by hand. Given this situation, the transition to transhipment by machine should be carried out in close cooperation with workers' representatives, in order to reduce as much as possible the damage that would be done to the workers. That this had not been done showed that the employers were only interested in their own profits. Therefore, wrote Van Rijswijk in conclusion, "may the success of this strike be followed by a complete victory of the workers, in order that the Rotterdam harbour, with its great reputation for speed and cheapness, may not be mechanized for the profit of a few, at the expense of thousands". ${ }^{68}$

The newspaper De Maasbode, mouthpiece of conservative Roman Cath-

67. Van den Berg, Elevator-kwestie, p. 23.

68. De Volksbanier, 23 November 1905. A similar position had already been taken by the Roman Catholic candidate for Parliament in one of the Rotterdam districts in September 1905, that is, before the outbreak of the strike. See Van den Berg, Elevator-kwestie, p. I3. After Van Term had been denounced by the leading Roman Catholic newspaper De Maasbode for his criticism of clerical dominance (apparently unrelated to the "elevator-kwestie"), his political career came to a quick halt and he returned to journalism. See De Maasbode, Io September 1905; De Tijd, I2, I5 and 16 September 1905 and 12 July 1907. The anti-unloader standpoint was repeated in De Volksbanier, e.g. 26 April, 24 May, 7 June and 28 June 1906. The paper is not preserved for the period July 1906 - July 1908 . 
olic opinion, repeated only the well-known cliché that technological progress "could not and should not" be stopped and that negotiations should end the problem. In its detailed accounts of the strike (it was a Rotterdam newspaper), it simply ignored Van Rijswijk's point of view, and so did the other leading Roman Catholic newspaper, De Tijd.

Finally, there were some individuals who tried to convince the workers of the need to strike against the unloaders. ${ }^{69}$ As far as the sources show, physical violence against the machines was never advocated and often condemned as useless. ${ }^{70}$ An interesting figure, whose views deserve special attention, was Sam van den Berg, an "ethical anarchist", opponent of socialist materialism, and hawker of the periodical Vrede (Peace, a journal produced by followers of the Social-Christian teachings of Leo Tolstoy). ${ }^{71} \mathrm{He}$ often spoke at public assemblies, was secretary of the Resistance Committee against the grain unloaders that combined the newly emerged organizations, and became the salaried secretary of the National Federation of Transport Workers in December 1907..$^{72}$ At the beginning of 1906, he published an interesting pamphlet about the conflict. Basically, his attitude was similar to that of the Roman Catholics and orthodox Protestants. ${ }^{73} \mathrm{He}$ too pleaded for a just order in the harbour, in which the workers were respected as much as anyone else. He said that the basic idea of socialism was that of brotherhood, while mainstream socialism had become materialistic and preoccupied with questions of power. Van den Berg portrayed the harbour as a community and the Unloader Company as an intruder, among whose shareholders were two bankers, a notary and a wine merchant: people who had nothing to do with the harbour and who were only in this business for the money (the same point was made in the protest song quoted at the beginning of his article and in the manifesto the Resistance Committee published in October 1905). ${ }^{74}$

The most interesting aspect of Van den Berg's standpoint was his criticism of the generally accepted theory of the inevitable and ultimately beneficial progress of technology, shared by socialist, Christian and liberal poli-

69. Their opinions are recorded, e.g. in Nieuwe Rotterdamsche Courant, I4 and I8 August I905 and Rotterdamsch Nieuwsblad, is August 1905.

70. See the anarchist M. van den Berg's angry reaction to the suggestion that he would have the unloaders towed to the sea: De Havenarbeider, 17 and 24 June 1905.

7I. See his De elevator-kwestie defence of this brochure by Van den Berg himself in De Havenarbeider, I2, 19 and 26 May 1906.

72. International Institute of Social History, Archief Nederlandsche Federatie Transportarbeiders, 1903-1908, letter of J. Brautigam to S. van den Berg, 8 December 1907.

73. There was a mutual sympathy between Van den Berg and Christian union leaders. Toenadering sometimes quoted him admiringly (28 November 1907) and Van den Berg quoted Roman Catholics Van Rijswijk and Term with approval in De elevator-kwestie, pp. 13, 25.

74. Ibid., pp. 25, 26; the manifesto was published in Voorwaarts, I4 October 1905. 
ticians alike. By this theory, Van den Berg said, union leaders confuse and paralyse the workers, inducing them to accept innovations fatalistically. Technology often does benefit society as a whole, but not necessarily and not always. In the case of the grain unloader, it is clear that only the employers will reap the benefits, and therefore the workers should resist its introduction. Since the machine would destroy employment on a massive scale, it made no sense to claim higher wages and shorter working hours: "wages and hours for whom?", he asked. It was therefore only natural that the workers protested and disregarded the artificial theories of their leaders. The only solution would be the creation of cooperative firms that would fight the capitalistic ones. When in the possession of the workers, machines would be beneficial to the community. ${ }^{75}$

Social-democrats like Spiekman and Wessels usually lumped Van den Berg together with noisy workmen's leaders like Ooykaas and Croiset, who regularly disturbed meetings by loudly accusing moderate union men of being "accomplices of capitalism" and "beasts of prey" and advocating "direct action" ${ }^{76}$ Social-democratic papers like Voorwaarts and the Havenarbeider called them "anarchists", who followed the dubious French idea of spontaneous general strikes or even violence to machinery and who would lead the workers to ruin. Organization, they repeated, should precede any action. $^{77}$

\section{SECOND INTRODUCTION, SECOND STRIKE}

At the beginning of 1907 the Unloader Company chose to take the offensive again, and there were several reasons for this. Some German importers had indicated that they would accept grain transhipped by machine, if it could be guaranteed that no strikes would occur and they suggested creating a new corps of weighers. A British shipping firm had informed its agent, who was on the board of the Unloader Company, that it wanted to use the services of the company for its ships, and from Hamburg came the news that another five pneumatic grain unloaders had been installed. ${ }^{7}$ The Unloader Company reached an agreement with nine Dutch importers, who were prepared to accept grain transhipped by machine. The company offered them

75. See, besides De elevator-kwestie, his Grepen uit de samenleving ('s-Gravenhage, 1906) and articles in Vrede, 8 (I905), pp. II8-II9 and I86-I88; the last was written by a "Jan Boezeroen", which may well be a pseudonym of Van den Berg. The idea of cooperative firms was also put forward in a short anonymous article in Sociaal Weekblad, II November I905.

76. Rotterdamsch Nieuwsblad, I5 August 1905; Voorwaarts, 25 November 1905.

77. See, for example, Spiekman in debate with Sam van den Berg's brother about "direct action" against the unloader, in De Bondsbanier, IO, 17 and 24 June, and 22 July 1905. See also Voorwaarts, I4 October and 4 November 1905. See also the discussion between the social-democrat Noordijk and Van den Berg about the latter's pamphlet in De Havenarbeider, 7 April 1905, and I2, I9 and I6 May 1906.

78. Cocheret, Het elevator-bedrijf, pp. 67-68. 
very low prices and guaranteed to pay for losses they might incur in the case of a boycott. ${ }^{79}$ Next, it created its own corps of weighers and dockworkers, who received relatively high wages. For this they needed the cooperation of the master stevedores, who claimed, and received, a high compensation. ${ }^{80}$ The cooperation of other employers was therefore dearly bought, but it was the beginning of a united front of employers, that would emerge victorious from the conflict. Finally, the company decided to use the unloaders in all cases where the bill of lading included the clause "as fast as steamer can deliver". Importers who would not accept their grain in this way would find their parcels pumped into a "captain's lighter" for which they would have to bear the costs. The German importers were informed of these decisions in a forceful letter, of which the unwritten message was that it was they, the owners of the Unloader Company, who were the bosses in the harbour. ${ }^{8 \mathrm{r}}$ The Germans, in reply, demanded the creation of a fund of half a million Marks, to be deposited at a German bank, to pay for any losses they might incur. When the Unloader Company chose not to answer, the Germans renewed the contract with the weighers, this time for three years. The contract gave the weighers higher wages, but prohibited them from striking.

The new offensive of the Unloader Company was accompanied by long articles in the leading newspapers in which the employers explained their position. As with the other groups participating in the debate, they couched their arguments about the unloader in general theories about technological development. Their point of view was entirely in line with the ideas of liberals and leading economists. One of them wrote:

One notices with surprise, that there are still many workers, and not only they, who even in the twentieth century believe that they have to take up the battle of the handicrafts against the progress of technology. But the history of the last hundred years teaches us that a machine that performs a job better, quicker and cheaper than a handicraft inexorably replaces that craft. On the other hand, the growth of commerce creates new jobs. Therefore we have to teach the worker to adapt to technological change. ${ }^{82}$

Another said that the basic question was whether workers should be allowed to block technological progress in the harbour. Without innovation Rotterdam would soon lose its competitive edge to other harbours, such as Antwerp and Emden, and even more workers would lose their jobs, he said. $^{83}$

79. Voogd, De graanelevators, pp. 25-26.

8o. Cocheret, Het elevator-bedrijf, pp. 73-74.

8I. Gemeente-archief Rotterdam, Archief Graan Elevator Maatschappij, no. 55, letter of 23 March 1907 .

82. Nieuwe Rotterdamsche Courant, I2 May 1907.

83. Schilthuis in Nieuwe Rotterdamsche Courant, 22 May 1907; cf. Rotterdamsch Weekblad, I8 May 1907; much earlier Plate, cited in De Havenarbeider, I6 July I904. 
The weighers' organization issued a protest against the creation of a new corps of weighers and dockworkers by the Unloader Company. The manifesto was signed by the AHAV, Toenadering and Kardinaal Manning, among others. ${ }^{84}$ When, at a meeting on 29 April 1907, the weighers called a boycott against those importers who had signed the contract with the Unloader Company, they again received the support of all the dockworkers' organizations, including the Protestant and Roman Catholic ones. At the end of the meeting, the "Elevator lied", quoted at the beginning of this article, was sung again. ${ }^{85} \mathrm{~A}$ successful strike of grain and ore workers in the port of Antwerp, and a dockworkers' strike in Hamburg, both taking place at this time, seem to have been important stimuli. ${ }^{86}$

Again, the Christian organizations of dockworkers received no support from their more powerful co-religionists. Patrimonium, the orthodox Calvinist working men's newspaper, quoted without comment articles from another paper in which actions against the unloaders were called senseless. ${ }^{87}$ Kuyper himself commented that one could not blame the strike-breakers, who were driven by poverty to accept jobs in the harbour, but that their arrival would result in increasing unemployment and social disorder, which would make a permanent military presence in the harbour necessary. ${ }^{88}$ That Kuyper more or less took sides with the people most hated by the dockers scabs and soldiers - shows the gulf between the leader and his followers in the harbour. The Roman Catholic Maasbode and De Tijd also ignored the standpoint taken by the Christian unions.

A kind of guerrilla war started between dockworkers and weighers on the one hand and the hated "scabs", who cooperated with the Unloader Company, on the other. The manager of the corps of strike-breakers had to be protected against the crowd by the police; he was even fired at. ${ }^{89}$ Since most seagoing ships contained parcels for more than one receiver, it often happened that on the same boat there were workers who were unloading grain by hand for the German importers, while the personnel of the Unloader Company was unloading another part for Dutch importers. The scabs were continually harassed. As soon as the police came to protect them, the other workers would lay down their work. The Unloader Company then proceeded to unload the whole ship by machine. In the course of the summer violence between workers and scabs increased. The mayor proclaimed a state of siege. Warships appeared in the harbour and troops intervened in the fighting between the workers.

The German importers soon realized that their contract with the weighers

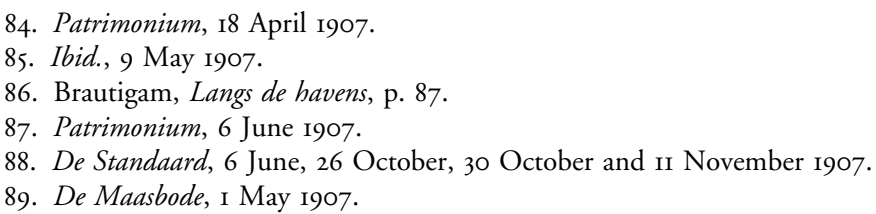


was backfiring. They came to Rotterdam to negotiate with the Unloader Company and in July all parties, including the workers' representatives, were trying to reach an agreement. The Unloader Company offered to raise wages, regulate working hours, limit the amount of grain transhipped by machine to Io per cent of the total amount during the next three years, allow weighers and other representatives of the importers to take part in the transhipment and to discuss the possible introduction of new unloaders with the workers' representatives. ${ }^{90}$ The parties came very close to an agreement. But when the Unloader Company suddenly added the condition that the workers they had employed as strike-breakers be recognized as normal workers and should therefore be entitled to the same conditions of work and payment, the workers' representatives turned the proposal down. ${ }^{91}$

The front of the employers on the side of the Unloader Company was now closing. Together with master stevedores and the Dutch importers, the company started a fund from which to pay the weighers' corporation, lawsuits and so on. ${ }^{92}$ When the workers wanted to negotiate again, the company refused to repeat its proposal. It said another firm was preparing to introduce unloaders, so it could not afford to wait any longer.

On Is September the strike broke out. The weighers did not take part in it, because they had received another raise in pay from the German importers and their contract forbade them to strike. The Christian unions did not participate, because they thought that the possibilities of reaching an agreement had not been sufficiently used by the workers' representatives. But there was a bitter note of resignation in their statements. They realized that they were too small to influence the course of events, especially since the employers were starting to form a united front. The Roman Catholic newspaper most concerned with social problems, Katholiek Sociaal Weekblad, wrote that new machines could not, "and in the interest of progress should not" be resisted - a grudging acceptance of the point of view of the leading Roman Catholic ideologists. It suggested, a bit late, that the municipal government exploit the machines, since an innovation with such effects upon the working population should not be left to private enterprise. ${ }^{93}$ Now that they rejected the strike, the Christian unions finally received the

90. The proposal is cited in Spiekman, "Een en ander", pp. 749-750.

91. Spiekman, "De staking in het graanbedrijf te Rotterdam", in Sociaal Weekblad, 28 September 1907, pp. 309-311.

92. Gemeente-archief Rotterdam, Archief Graan Elevator Maatschappij, no. 55, "Contract van cargadoors, [...] etc". The failure of the employers at the first strike may be explained by the fact that they organized themselves much later than in other ports, which has to do with the relatively small presence of liner companies and the prevalence of tramp shipping. See Broeze, "Militancy and Pragmatism", pp. 178, 195, and Jansen, "'De wil der bazen'”, pp. 52-53.

93. Toenadering, 3I October 1907; "Manifest. Aan de bootwerkers van Rotterdam!", 23 September 1907, by Toenadering, Gemeente-archief Rotterdam, collection "pol. vakbonden alf.". For the Roman Catholic standpoint, see: Katholiek Sociaal Weekblad, 26 October 1907 and 2 July 1910. 
support from their national superiors. ${ }^{94}$ Like Abraham Kuyper in De Standaard, Roman Catholic papers emphasized the violent behaviour of the strikers and praised the soldiers who kept a minimum of order in the harbour.

The AHAV lent the strikers its support with some hesitation. Spiekman defended this standpoint. He did not speak any more about abolishing the machines and stressed the reasonableness of the wage claims of the workers, in the light of the wage increase the weighers had obtained. ${ }^{95}$ But other important social-democratic leaders rejected the strike. ${ }^{96}$

While the conflict was running its course, the company was raising money for buying new unloaders. In its prospectus it stated explicitly that its goal was "to establish complete control of the transhipment and weighing of grain in the harbour of Rotterdam". ${ }^{97}$ This time it was no problem to raise money. On the contrary, Dutch and German importers and the shipowners who were the original shareholders tried to secure as large a share in the new company as they could get. ${ }^{98}$ It was clear that after the German importers had withdrawn their support, the workers had already lost the battle, even before it had begun. Scabs, recruited from all over the Netherlands and from Germany, replaced regular workers. ${ }^{99}$ Strike funds were far too small to sustain a long strike, and on 2r November the strike was called off. The employers, who were by now united in a formal organization (the Scheepvaart Vereeniging Zuid) could dictate the terms of the peace. Five years later there were sixteen unloaders, which together transhipped more than 90 per cent of the grain that arived in Rotterdam (Figure 5). ${ }^{100}$ While in 1907 Rotterdam had lost some of its grain trade to Antwerp, after 1908 it soon recovered its share and outstripped other ports. In I909, Rotterdam received 3.5 million tons of grain (it had been 2.6 million tons in $1904^{\mathrm{IOI}}$ ), against Antwerp 2.9, Hamburg 2.3, London less than 2 million and Liverpool I.6. ${ }^{\text {Io2 }}$ In spite of this growth, unemployment must have increased considerably, since the number of workers needed in transhipment had decreased by 32 per cent, ${ }^{\mathrm{IO}}$ and other sectors of the ports, such as the

94. Patrimonium, 3 and 17 October 1907.

95. Sociaal Weekblad, 28 September 1907.

96. See also Spiekman's account of this final phase in the conflict, Sociaal Weekblad, 28 September 1907. Cf. Polak, cited in Cocheret, Het elevator-bedrijf, p. I03; and Voorwaarts, 23 November 1907. 97. Gemeente-archief Rotterdam, Archief Graan Elevator Maatschappij, no. 2A, "Prospectus II". Cf. letter to the French engineering firm Terrin in Marseille, dated 5 September 1907, where the director of the Company asks Terrin to please hurry, "because of the present strike": ibid., no. $2 \mathrm{~B}$. 98. Cocheret, Het elevator-bedrijf, pp. Io6-Io9.

99. De Tijd, 3 and $14-17$ October I907.

Ioo. Everwijn, Beschrijving van Handel en Nijverheid, p. 64I; Serton, Rotterdam als haven, p. 39.

IOI. Het Volk, 2i November I905.

IO2. Serton, Rotterdam als haven, pp. II5-II6.

I03. Van der Waerden, Geschooldheid en techniek, pp. 222-225. 


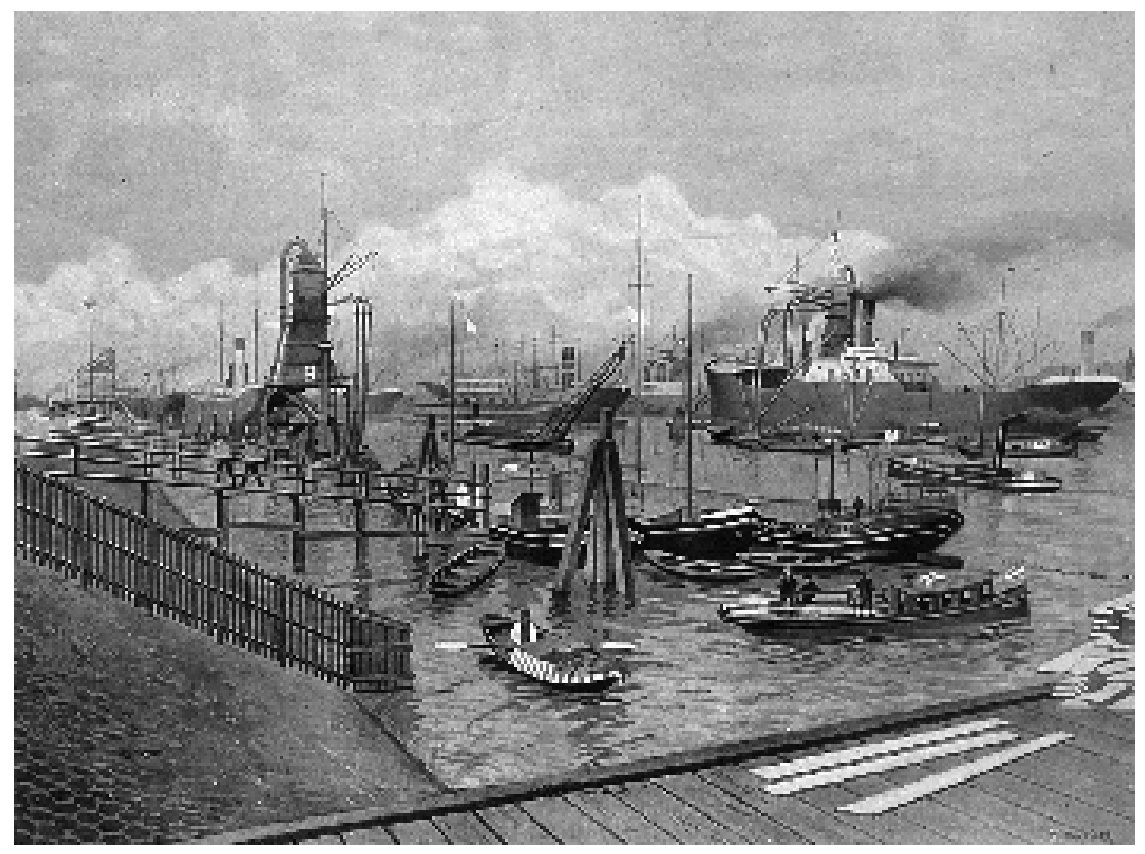

Figure 5 . The grain unloader as part of the regular "harbour furniture". School plate by B. Beuninck, colour print, 1946 (Gemeentelijke Archiefdienst Rotterdam)

transhipment of ore, had also been mechanized; the recession of 1908 made things even worse. ${ }^{\mathrm{IO}}$

\section{CONCLUSION: DOMINANT IDEOLOGY AND RESISTANCE TO MACHINERY'OS}

This article started from the proposition that in the Netherlands a "dominant ideology of technology” existed, which was seriously though unsuccessfully contested during the crisis surrounding the introduction of the pneumatic grain unloaders in Rotterdam harbour. It is now time to substantiate this claim and to assess the role of ideology in the conflict.

104. Serton, Rotterdam als haven, p. 42. It is impossible to give an adequate account of employment in Rotterdam harbour, because of a lack of statistics, which is accounted for by the fact that most dockworkers had casual jobs. See Van IJsselstein, Rapport, p. 7; Buitengewone werkloosheid onder de havenarbeiders te Rotterdam, winter 1908/1900 [Report of the Burgerlijk Armbestuur to the mayor of Rotterdam about excessive unemployment in Rotterdam], at the Gemeente-archief Rotterdam.

I05. The following discussion has been inspired by N. Abercrombie, S. Hill and B.S. Turner, The Dominant Ideology Thesis (London, 1980). 
The existence in the Netherlands (as well as in other Western European countries) around 1900 of a consensus among leading groups about the social role of technological change has been argued elsewhere. ${ }^{\mathrm{I}}{ }^{\mathrm{g}}$ It involved a wholehearted acceptance by the leaders of liberalism, socialism, Roman Catholicism, and orthodox Protestantism of new technology, defined as a set of ethically neutral though powerful tools, developing practically autonomously, the social impact of which was determined entirely by the way it was applied. Technology itself was therefore "depoliticized": it was not a subject of political debate. ${ }^{107}$ Disagreement among the four ideological groupings concentrated upon the context in which technology was to be applied, the order of society: in that sense not one dominant ideology existed, but at least four. What I call the "dominant ideology of technology" was therefore an area of overlap between the main ideological currents in the Netherlands during this period. Its dominance was demonstrated by the fact that its basic terms and ways of reasoning determined the pattern of practically all the articles and speeches which have been discussed in this article. It is highly probable that leading groups - employers, politicians, labour union leaders, priests - thought in these terms.

The conflict about the grain unloaders has shown first of all that many workers did not share this ideology. At least since the I88os, the introduction of several innovations had provoked fierce resistance. Not only workers but local labour leaders, whether socialist or Christian, also could be very critical of the desirability and inevitability of technological progress. They did not share the stoic acceptance of unemployment and poverty that the dominant ideology implied and they realized that following their national leaders in this respect would come down to abandoning their men (with the very probable consequence of the men abandoning them). The most direct attack upon the technological determinism of the dominant ideology was launched by the Christian socialist Van den Berg, who argued that this ideology was designed to paralyse the workers' resistance by trying to convince them that no one could change the direction of technological development. He tried to show that the introduction of the machines was the result of choices that could be contested; he attempted, in other words, to repoliticize technology.

This direct attack was typical of someone in Van den Berg's marginal position, but it was not the usual strategy of local leaders. Men like Spiekman, Van Rijswijk and the leaders of Toenadering realized that in order to be successful, they had to win over their superiors, that is, socialist and Christian politicians and union leaders at the national level. They attempted to do this by formulating their positions as much as possible in terms of the dominant ideology. They tried to show that resistance to the unloaders

I06. Van Lente, "Ideology and Technology".

I07. Cf. L. Winner, "Do Artifacts have Politics?", in idem, The Whale and the Reactor (Chicago,

1986), pp. 19-39 
was a logical consequence of this ideology. Thus Spiekman argued that the machines could not possibly be seen as serving the interests of the workers or even the harbour as a whole. The class struggle implied resistance to those technologies which served only the interests of the employers while harming the workers. Toenadering implicitly used Kuyper's theories of a corporate society to claim that workers had to be consulted on mechanization, a view that was shared by Kardinaal Manning.

This tour de force failed, because the dominant ideology was designed to make the development of industrial society acceptable. Socialist leaders fought out their ideological disagreement in their newspapers and periodicals, with the result that Spiekman was marginalized and Van den Berg was lumped together with noisy, unthinking "anarchists". The leaders of the Christian parties simply ignored the arguments of their Rotterdam brothers and eventually took sides with the forces of repression. It was not in their interest to identify with one group of workers: their object was to create a trans-class movement, that would appeal to all strata of society, and this made it impossible for them to resist innovations that were warmly supported by the employers. The opposition to the grain unloaders therefore remained an expression of local interests, those of the grain workers in Rotterdam: it could not be linked to the interests of broader or more influential groups.

In this respect, the "elevator-kwestie" differed fundamentally from the prime example of workers' resistance to modern industrial technology: the battle of the British textile workers against machinery in the late eighteenth and the early nineteenth centuries. These men received the powerful support of many wealthy landowners, who feared mass unemployment (for which they, as the most important ratepayers, would have to pay), the rise of a new elite of businessmen and a general disruption of the traditional order. ${ }^{\text {I08 }}$ This coincidence of interests, which in Britain produced a powerful movement for the regulation of industry during the I830s and I840s, disappeared both in England and elsewhere after I850. In the Netherlands, it had never existed.

Ultimately, much of the debate about the grain unloaders revolved around the concept of "order": the organization of the harbour and who was to have a say in it. ${ }^{109}$ The employers claimed control of the introduction of new machinery. This machinery was in itself a means to re-establish control over transhipment procedures which as a consequence of a growth

I08. A. Randall, Before the Luddites (Cambridge, 199I). Cf. Abercrombie et al., Dominant Ideology Thesis, pp. 95-97; D. van Lente, "The Critique of Industrial Technology in the Netherlands and Other Western Countries in the Nineteenth Century", in D.C. Christensen (ed.), European Historiography of Technology (Odense, 1993), pp. 55-67.

I09. The following owes much to the concept of a "crisis of control" that developed in Western countries at the end of the nineteenth century. See J.R. Beniger, The Control Revolution (Cambridge, Mass., 1986) and R. Edwards, Contested Terrain (London, 1979). 
in scale and speed of transportation had become increasingly chaotic. In the course of the conflict, the employers learned that they had to cooperate, in spite of their sometimes divergent interests. Only by taking a common stand and by introducing more machines could they crush the workers' resistance and show the powerful German importers who was the boss in the harbour.

The mirror image of the employers' idea of control was that of the leaders of the "modern" union AHAV. Men like Wessels wanted a disciplined workers' movement that could negotiate on a regular basis with the employers, with the strike only as an ultimate weapon. These complementary ideas of order led, much later, to more regular labour relations, mediated by employers' and working men's associations. ${ }^{\text {IIO }}$

The most suppressed view of order, only articulated by Van den Berg and Toenadering, was the idea of the harbour as a community and of the unloaders as intruders. ${ }^{\text {III I }}$ It is impossible to be certain about the opinions of the dockworkers, but there seems to have been a basic sense among them that the employers had no right to impose a machine that would deprive hundreds of them of their daily bread. ${ }^{\mathrm{II} 2}$ This idea was clearly expressed in the anonymous protest song quoted at the beginning of this article, which according to newspapers was often sung after meetings. It may also explain the vehemence with which violence (or accusations of planning violent action) was rejected, even by radicals like Van den Berg's brother. The only violence that actually occurred was directed against scabs, men imported from outside Rotterdam (that is, from outside the community) in order to break the strike. Feelings against these men were exceedingly bitter, they were manhandled and thrown overboard during the fights in May 1907, and an impending agreement in the summer of 1907 failed essentially because the employers refused to disband their corps of strike-breakers.

The final result of the struggle was, to borrow David Noble's phrase, "preservation through change": ${ }^{113}$ the massive transformation of grain transhipment did not result in fundamental changes in ways of interpreting and implementing technology. The leading groups simply found their views confirmed. The dominant ideology of technology remained the standard text for discussing technological change until the I970s, when labour unions tried to repoliticize the problem of innovation. ${ }^{\text {II }}$ There is no reason to

IIO. Rotterdam therefore moved with the general tendency, described by Broeze, from militant radicalism, via syndicalist failure, to reformist pragmatism. See Broeze, "Militance and Pragmatism", p. 186

III. Literally, the word intruder occurs in Van den Berg, De elevator-kwestie, p. 26.

II2. See also the pamphlet addressed to the Rotterdam grain workers by the combined working men's associations in August 1905, written by Wessels, cited by Van den Berg, De elevator-kwestie, p. IO.

II3. D.F. Noble, America by Design (Oxford, 1977), ch. 4.

II4. See, for example, H.C. Boekraad et al., Arbeidsproces en technologie, special issue of Te elfder ure, 27, I (May 1983). 
believe that the workers were converted to this technological optimism: they simply learned to accept the inevitable. Not until the introduction of containers in Rotterdam harbour did the workers resist new machinery again. ${ }^{\text {II }}$

II5. E. Nijhof, "Innovaties en werkgelegenheid in de haven van Rotterdam (I890-heden)", in C. Lorenz et al. (eds), Geschiedenis tussen eigen ervaring en wetenschap (Utrecht, 1990), p. 28. 
